\section{Clinico-pathological characteristics of canine gingival squamous cell carcinoma}

\author{
Fatemeh Namazi, ${ }^{1}$ Neda Ranjbar Kohan, ${ }^{2}$ \\ Mina Afsar,2 Amir Allahdin,2 \\ Saeed Nazifi2 \\ 1Department of Pathobiology, \\ 2Department of Clinical Studies, School \\ of Veterinary Medicine, Shiraz University, \\ Iran
}

\begin{abstract}
In the present study, a case of gingival squamous cell carcinoma is described in a 9-yearold sheepdog with a swelling of the left mandible. Plain radiographs of the head revealed a soft tissue mass behind the ventral border of the left mandible. At necropsy, the tumor presented as reddish-brown ulcerated and irregular tumoral masses of the gingiva. In the cytology smear, there were oval to angularshaped squamous epithelial cells with varying immaturity and variable staining and nuclear to cytoplasmic ratios (N:C). Some of the cells showed dyskeratosis. Histopathologically, the tissue sections were composed of the cords and islands of squamous epithelial cells with an abundant eosinophilic cytoplasm, large and ovoid nuclei with a prominent nucleolus. The mitotic figures were moderate. Based on the histopathological findings, the tumor was diagnosed as a moderately differentiated gingival squamous cell carcinoma.
\end{abstract}

\section{Introduction}

Squamous cell carcinoma is, by far, the most important skin tumor affecting most external sites, but is less reported affecting the internal organs. Oral cancers constitute approximately $2-4 \%$ of all malignant tumors in humans. ${ }^{1}$ Malignant tumors of the oral cavity, approximately $6 \%$ of all malignant neoplasms, are one of the most common cancer types in dogs. ${ }^{2}$ Approximately 85 to $90 \%$ of all oral cancers are squamous cell carcinomas in humans, ${ }^{3}$ whereas they account for approximately $20 \%$ of oral tumors in dogs. 4 The prevalence of tumor increases with advancing age, and there is no gender and breed predilection. ${ }^{5}$

Squamous cell carcinomas have localized neoplastic invasion into the adjacent stroma or subepithelium including local bone invasion and only $10 \%$ of tumors spread to regional lymph nodes and $3 \%$ metastasize to the lungs. ${ }^{6}$
Squamous cell carcinoma arising from internal sites such as tonsils, gastric epithelium, and urinary bladder does not share the relatively innocuous behavior of those initiated by sunlight, which are slow to metastasize, usually only to local lymph nodes. ${ }^{7}$

The clinical forms of gingival squamous cell carcinomas are quite variable, exhibiting an ulcerated area or an exophytic, granular or verruciform growth, easily leading to misdiagnosis with benign tumors or other inflammatory responses. ${ }^{8}$

This report describes the clinical signs and histopathological findings of moderately differentiated gingival squamous cell carcinoma in 9 -year-old sheepdog.

\section{Case Report}

A 9-year-old male sheepdog was referred for clinical evaluation of an asymmetrical swelling of the mandibular region. The dog had a clinical history of lethargy, poor appetite and weight loss. At clinical examination, there was a firm mass behind the ventral border of the left mandible. The dog had a rectal temperature of $38.2^{\circ} \mathrm{C}$ and was depressed. Complete blood count (CBC), biochemical analysis and radiography from head and thorax were performed. $\mathrm{CBC}$ and serum biochemical results and thoracic radiographs were normal. Plain radiographs of the head revealed a soft tissue mass behind the ventral border of the left mandible.

Because of very poor clinical condition, the possibility of severe bleeding during the operation and possible post operative complications, including injury to salivary duct, lingual dysfunction and probability of the lifelong necessity of tube feeding, the owner elected to euthanize the dog.

Grossly, a reddish-brown ulcerated and irregular mass of approximately $5 \times 5 \times 5 \mathrm{~cm}$ in diameter was observed within the gingiva and demonstrated a firm consistency. Some enlarged lymph nodes were observed and removed.

The tissue samples were fixed in 10\% neutral buffered formalin, embedded in paraffin, sectioned at $5 \mu \mathrm{m}$ and stained with Hematoxylin \& Eosin for light microscopic examination.

In the cytology smear, oval to angularshaped squamous epithelial cells with varying immaturity and variable staining and nuclear to cytoplasmic ratios (N:C) were seen. Some of the cells showed dyskeratosis. Histopathological features revealed the cords and islands of squamous epithelial cells, which extended into the submucosal layer. The tumor cells were large and had an abundant eosinophilic cytoplasm, large and ovoid nuclei
Correspondence: Saeed Nazifi, Department of Clinical Studies, School of Veterinary Medicine, Shiraz University, Shiraz, P0 Box: 1731- 71345, Iran.

Tel.: +98.711.228.6940 - Fax: +98.711.228.6950.

E-mail: nazifi@shirazu.ac.ir

Key words: Dogs; gingiva; metastasis; squamous cell carcinoma.

Contributions: the authors contributed equally.

Conflict of interest: the authors declare no potential conflict of interest.

Received for publication: 14 March 2015.

Accepted for publication: 1 April 2015.

This work is licensed under a Creative Commons Attribution NonCommercial 3.0 License (CC BYNC 3.0).

(C) Copyright F. Namazi, et al., 2015

Licensee PAGEPress srl, Italy

Veterinary Science Development 2015; 5:5903

doi:10.4081/vsd.2015.5903

with a prominent nucleolus. Keratin tonofibers were seen to some degree. The mitotic figures were moderate (Figure 1). Similar neoplastic cell islands were also detected in the regional lymph nodes. Hence, the mass was found to be a moderately differentiated squamous cell carcinoma.

\section{Discussion and Conclusions}

The tissue sections from this case revealed a malignant tumor of epidermal cells in which the cells showed differentiation of keratinocytes with an abundant eosinophilic cytoplasm and large nuclei. With the exception of the tonsillar tissue, the gingiva are more often affected than the other soft tissues and most frequently affected at the maxilla. In the present case, the neoplastic mass was found to originate from the gingiva of the ventral border of the left mandible.

Squamous cell carcinoma is, by far, the most important skin tumor, but less reported affecting the internal organs. Squamous cell carcinoma in dogs infrequently involves the eye. ${ }^{9}$ Occurrence on multiple digits simultaneously or consecutively is seen in dogs in a low percentage of cases. ${ }^{10} \mathrm{~A}$ single squamous cell carcinoma is reported arising from the pyloric gland mucosa in a dog. ${ }^{11}$ Squamous cell carcinoma occurs most often in the urethra of bitches. ${ }^{12}$ Squamous cell carcinoma of the thyroid is an infrequent tumor in animals, but only occasionally encountered. ${ }^{7}$ 


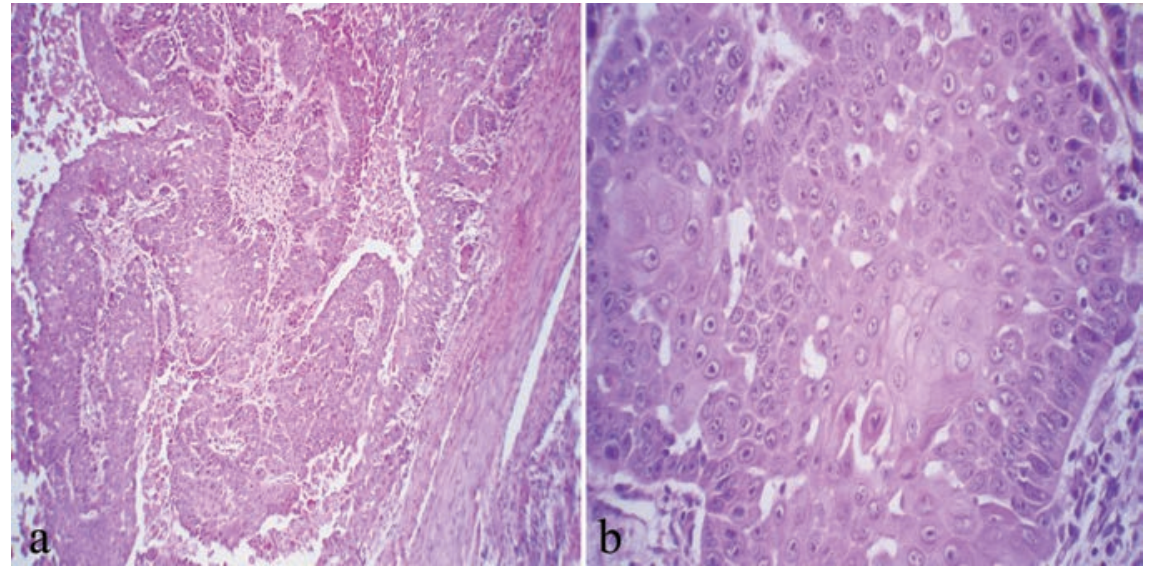

Figure 1. a) The cords and islands of squamous epithelial cells, H\&E $(\times 180)$. b) The neoplastic cells consisted of large cells with abundant eosinophilic cytoplasm, ovoid nuclei and a prominent nucleolus, $H \& E(\times 720)$.

Gingival squamous cell carcinoma is the second most common malignant neoplasm of the canine oral cavity. Only $10 \%$ of tumors spread to regional lymph nodes and $3 \%$ metastasize to the lungs. ${ }^{13,14}$ Despite the low percentage of metastasis of squamous cell carcinomas, the present neoplastic cells were also seen in the regional lymph nodes.

There are several factors associated with the development of a squamous cell carcinoma, including prolonged exposure to ultraviolet light, lack of pigment within the epidermis at the sites of tumor development. 15 The etiology of oral squamous cell carcinoma is unclear in dogs. 16 In humans, induction of cyclo-oxygenase-2 has been implicated in the oncogenesis of various cancers, including squamous cell carcinomas. Oral squamous cell carcinoma in dogs can also be associated with overexpression of cyclo-oxygenase-2.17 In addition, poor oral hygiene associated with chronic inflammation may promote the development of oral cancer. ${ }^{8}$

Based on histopathological findings, a gingival squamous cell carcinoma was diagnosed.

\section{References}

1. Barbone F, Franceschi S, Talamini R, et al. A follow-up study of determinants of second tumor and metastasis among subjects with cancer of oral cavity, pharynx, and larynx. J Clin Epidemiol 1996;49:36772 .

2. Dorn CR, Taylor D0, Schneider R, et al. Survey of animal neoplasms in Alameda and Contra Costa Countries, California. II. Cancer morbidity in dogs and cats from Alameda county. J Natl Cancer Inst 1968;40:307-18.

3. Funk GF, Karnell LH, Robinson RA, et al. Presentation, treatment, and outcome of oral cavity cancer: a national cancer data base report. Head Neck 2002;24:165-80.

4. Brodey RS. A clinical and pathologic study of 130 neoplasms of the mouth and pharynx in the dog. Am J Vet Res 1960;21:787812.

5. Harvey CE, Emily PP. Periodontal diseases in small animal dentistry. St Louis: Mosby; 1993. pp 89-144.

6. Head KW. Tumors of the alimentary tract. In: Moulton JE, ed. Tumors in domestic animals. Berkeley: University of California Press; 1990. pp 347-428.

7. Saik JE, Toll SL, Diters RW, Goldschmidt MH. Canine and feline laryngeal neoplasia: a 10-year survey. J Am Anim Hosp Assoc 1986;22:359-65.

8. Li PY, Auyeung L, Huang SC. Squamous cell carcinoma of the mandibular gingiva. Chang Gung Med J 2004;27:777-81.

9. Wilcook B.P. Squamous cell carcinoma. In: Jubb KVF, Kennedy PC, Palmer N, eds. Pathology of domestic animals. 4th ed. San Diego: Academic Press Inc.; 1993. pp 512515.

10. Liu S, Hohn RB. Squamous cell carcinoma of the digit of the dog. $\mathrm{J}$ Am Vet Med Assoc 1968;153:411-24.

11. Patnaik AK, Lieberman PH. Gastric squamous cell carcinoma in a dog. Vet Pathol 1980;17:250-3.

12. Davies JV, Read HM. Urethral tumors in dogs. J Small Animal Pract 1990;31:131-6.

13. McCaw DL, Pope ER, Payne JT. Treatment of canine oral squamous cell carcinomas with photodynamic therapy. Br J Cancer 2000;1297-9.

14. Liptak JM, Withrow SJ. Cancer of the gastrointestinal tract. Section A: oral tumors. In: Withrow SJ, Vail DM, eds. Withrow \& MacEwen's small animal clinical oncology. St Louis: Saunders Elsevier; 2007. pp 455475.

15. Meuten DJ. Tumors in domestic animals 4th ed. Iowa: Iowa State Press; 2002. p 51.

16. Vrieling HE, Schepman KP, Theyse LP, Van der Waal I. Oral carcinoma in 34 dogs. Ned Tijdschr Tandheelkd 1999;106:122-5. [Article in Dutch]

17. Pestili de Almeida EM, Piché C, Sirois J, Doré M. Expression of cyclo-oxygenase-2 in naturally occurring squamous cell carcinomas in dogs. $\mathrm{J}$ Histochem Cytochem 2001;49:867-75. 